\title{
Periodontitis and risk for preeclampsia - a systematic review
}

\author{
Tomasz Konopka®i, Aneta Zakrzewska(D) \\ Departament of Periodontology, Wroclaw Medical University, Poland
}

\begin{abstract}
Objectives: The aim of the study is to review systematic cohort and randomized trials on the relationship between periodontitis and preeclampsia. Periodontitis is an independent risk factor for preeclampsia (PE), and periodontal treatment could play a significant role in the prevention of this pregnancy complication.

Material and methods: A total of 821 items (published until March 2019), thematically related to the relationship between periodontitis, its treatment and the incidence of preeclampsia, were collected from the databases of PubMed, Scopus, Google Scholar and the Polish Database of Medical Bibliography and analyzed. In the end, 6 cohort studies and 3 randomized controlled trials (from the years 2003-2016) were deemed eligible for the review. The main exclusion criteria were as follows: case-control and cross-sectional studies, medical and dental conditions.

Results: A significant relationship between periodontitis and the risk for developing preeclampsia was demonstrated in 5 cohort trials, which was not confirmed by only 1 study. A total of 2724 pregnant women, including 195 (7.16\%) with PE, were analyzed. In 3 randomized trials which assessed the impact of non-surgical treatment (scaling and root planing = SRP) on the occurrence of preeclampsia, the preventive effects of the implemented treatment was not confirmed. A total of 116 women from the group of 1825 pregnant subjects undergoing the non-surgical treatment (SRP) and 116 women from the control group of 1827 pregnant women were subsequently diagnosed with PE, which amounted to $6.30 \%$ and $6.35 \%$, respectively.

Conclusions: The cohort studies indicated that periodontitis may result in an increased risk for developing PE. A more detailed analysis regarding the impact of potential risk factors and modification of further studies (clarification of how periodontitis and preeclampsia should be defined in observations, consideration of disease severity, earlier at 12-16 weeks of gestation - implementation of the non-surgical treatment, modification and extension of the classical protocol of the non-surgical treatment of periodontal diseases, as well as conducting European studies), are necessary due to considerable discrepancies in the available literature sources (cohort and randomized observations).
\end{abstract}

Key words: periodontitis; periodontal therapy; adverse obstetric outcomes; preeclampsia; systematic review

Ginekologia Polska 2020; 91, 3: 158-164

\section{INTRODUCTION}

Periodontitis is a chronic and multifactorial inflammatory disease associated with advanced dysbiosis of the pathogenic bacterial biofilm in periodontal pockets, which leads to a progressive destruction of the periodontal attachment apparatus. Periodontal pathological processes include high biomass of periopathogens (Porphyromonas gingivalis, Tannerella forsythia, Treponema denticola, Aggregatibacter actinomycemecomitans, Filifactor alocis and Catonella morbi) in the biofilm on the root surface, progressive character of the inflammatory process in the connective tissue and bone resorption of the alveolar ridge, as well as excessive reactivity of the host immunological-inflammatory response to the bacterial biofilm. Periodontitis is a social disease - the most recent nationwide epidemiological study has demonstrated that it occurs in approximately $30 \%$ of the Polish population between the ages of 34 and 45 years [1]. Confirmed risk factors include the non-modifiable (age, sex, race and genotype) and the modifiable (smoking, poorly controlled diabetes, presence of perio-pathogens in the subgingival biofilm, poor oral hygiene, obesity and the metabolic syndrome, osteoporosis, low social and economic status, stress, and poor-quality diet) causes [2]. According to the Polish epidemiological reports, periodontitis is diagnosed in $11-12 \%$ 
of all pregnant women $[3,4]$. Periodontitis is a risk factor for diabetes and a likely risk factor (evidence from case-control and cohort studies; no evidence from interventional studies) for cardiovascular diseases and their endpoints - myocardial infarction, stroke, CVD mortality, low birth weight and/or preterm birth, and chronic renal failure $[5,6]$.

Pre-eclampsia (PE) is a hypertensive disorder characterized by signs of damage to another organ system, which typically develops after 20 weeks of gestation. PE has been estimated to occur in 2-8\% of all pregnant women and is currently considered to be the second main cause of maternal and perinatal mortality $[7,8]$. The most common maternal PE- and hypertension-related complications include a generalized tonic-clonic convulsion, disseminated intravascular coagulation, liver failure and acute renal failure with proteinuria, bleeding to the central nervous system and retina, HELLP syndrome, congestive heart failure, pulmonary edema, placental abruption and cesarean delivery [9]. Fetal $\mathrm{PE}$ - and hypertension-related complications include the risk for admission to the neonatal intensive care unit, intrauterine growth restriction, low birth weight, prematurity, intrauterine fetal demise, and early infant mortality [9]. Risk factors for PE include: age (> 35 years), race (African-American), (family) history of $\mathrm{PE}$, multiple gestation, intrauterine growth restriction, obesity, chronic hypertension, pharmacological interventions for the induction of the ovulation, pregestational diabetes mellitus type I or II, gestational diabetes mellitus, systemic lupus, and the antiphospholipid syndrome $[9,10]$. Chronic maternal infections (e.g. urinary tract infections) are indicators of PE-related risk. In 2002, Riché et al. [11], were the first to publish the results of a cohort study at Chapel Hill, North Carolina, on the relationship between periodontitis and the development of preeclampsia.

\section{Objectives}

The aim of this systematic review is to present cohort and randomized trials on the relationship between periodontitis and preeclampsia. A confirmed role of periodontitis as an independent PE-related risk factor would play a vital role in the prevention of this obstetrical syndrome.

\section{MATERIAL AND METHODS}

A systematic review of the literature was conducted in accordance with the Preferred Reporting Items for Systematic Reviews and Meta-Analyses (PRISMA) [12].

Questions for the review:

1. Do the adjusted odds ratio values indicate an independent influence of periodontitis on the occurrence of $\mathrm{PE}$ in cohort studies about the relationship between periodontitis and preeclampsia?

2. Does periodontal treatment significantly reduce the incidence of PE?
These questions concerned population-based and non-experimental cohort and randomized control trials (CCTs or RCTs).

The review covered all publications in English, German, Polish and Russian about the relationship between periodontal diseases and preeclampsia, as well as the influence of periodontal treatment on PE-related morbidity.

The inclusion criteria were as follows: pregnancy with no PE symptoms before 20 weeks of gestation (blood pressure $>140 / 90 \mathrm{~mm} \mathrm{Hg}$ and proteinuria). The exclusion criteria included (family) history of $\mathrm{PE}$, incidence of $\mathrm{PE}$ in multiparous women, intrauterine growth restriction, pharmacologically treated hypertension, pharmacologically stimulated ovulation, pregestational diabetes mellitus type I or II, gestational diabetes mellitus, systemic lupus, antiphospholipid syndrome, and fewer than 10 teeth.

All information was obtained from electronic databases. Electronic searches were conducted in PubMed, Scopus, Google Scholar and the Polish Medical Bibliography Databases. All texts were published until the end of March 2019 were figured in. When searching potential papers, the following keywords were used: periodontitis or periodontal disease or periodontal treatment in combination with at least one of the following terms: preeclampsia, pre-eclampsia, pregnancy outcomes, pregnancy complications. The obtained articles were subsequently checked independently by both authors (TK, AZ) against the inclusion and the exclusion criteria.

The first selection eliminated all the abstracts, case descriptions, reviews, animal studies, in vitro studies and repeated publications. Subsequently, the texts of the original works were verified against the inclusion criteria (inter alia, with the above definitions of preeclampsia and periodontitis only in accordance with the clinical probing depth and/or clinical attachment loss) and the exclusion criteria (case-control and cross-sectional studies were excluded). If the trial was repeated in the same center, the subsequent study was taken into consideration. The relationship between periodontitis and PE (Odds Ratios - ORs) as well as the effect of periodontal treatment on the risk for developing PE (Risk Ratios - RRs) had to be determined in the studies qualified for the review. The decisions of the authors were compared at the end of the review and the text was included in the analysis only when mutual consensus was reached.

Each study-related entry, independently obtained by both authors (TK, AZ), included the name of the author(s), year of publication, country of study, sample size, age of the examined women, definition of periodontitis, time of study, and in case of the periodontal treatment - time of treatment and its type, OR (RR) as well as $95 \%$ confidence interval $(\mathrm{Cl})$ values and statistical adjustments for the confounding factors. 


\section{RESULTS}

The initial review of the literature identified 821 items thematically related to the relationship between periodontitis, its treatment and the development of preeclampsia. After careful analysis, 16 articles, meeting the inclusion and the exclusion criteria, were selected. The last scrutiny excluded 2 cohort studies conducted previously in the same center $[11,13], 3$ studies with end points which differed from the accepted ones [14-16], and 1 study with inadequate methodology [17]. In the end, 6 cohort studies [18-23] and 3 randomized control trials (RCTs) [24-26] were deemed eligible for the review. The process of selecting works for the systematic review is presented in Figure 1.

Table 1 summarizes the eligible cohort studies conducted between 2003 and 2016. A significant relationship

Records identified in electronic databases:

PubMed: 125, Scopus: 134, Google Scholar: 561, Polish Medical Bibliography: 1

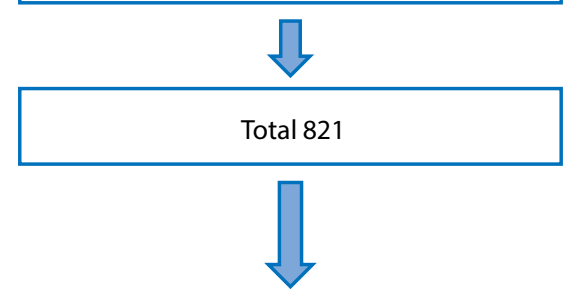

131 records screened

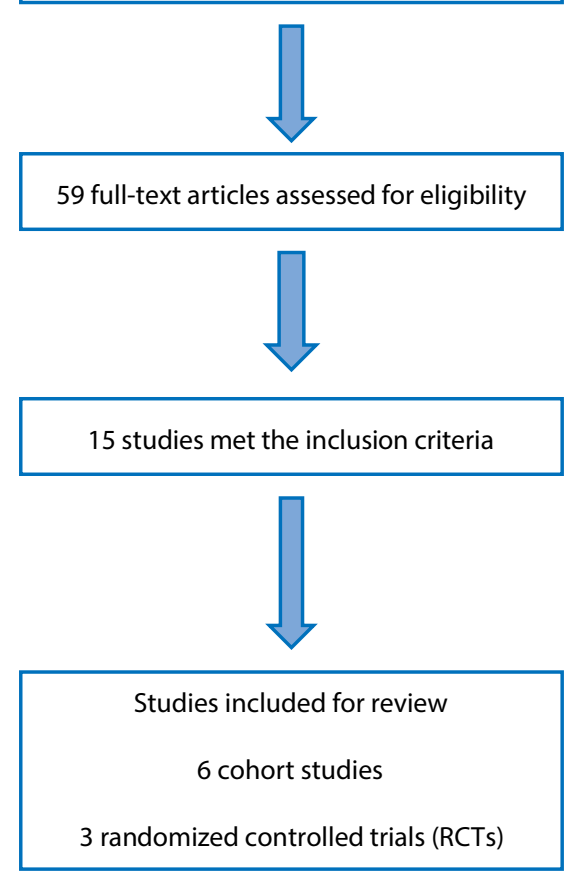

between periodontitis and PE was confirmed by 5 sources [18, 20-23] and not verified by only 1 [19]. A total of 2724 pregnant women were assessed, with 195 (7.16\%) diagnosed with PE. These observations were conducted in the USA, India, Korea and Canada. The diversified pool of confounding factors, which were being regarded in the multi-factor analysis of the modelling process, was strongly emphasized.

Table 2 presents 3 randomized studies which assessed the impact of non-surgical treatment (scaling and root planing - SRP) on the morbidity of mothers with PE. None of them confirmed the protective effect of the periodontal treatment on developing PE. Non-surgical periodontal treatment (removal of subgingival deposits with scaling and root planing along with the application of an antiseptic in the
First elimination: abstracts, duplicated and irrelevant titles - 690
Second elimination: case and review articles, language -72

Third elimination: failure to meet the iclusion criteria, mainly case-control studies -44
Articles excluded with reasons:
Previous study $-2(11,13)$
Uninteresting outcome3 (14-16) Methodology - 1 (17)

Figure 1. Flow chart of the study selection process for the systemic review 


\begin{tabular}{|c|c|c|c|c|c|c|}
\hline Study/Year & $\begin{array}{l}\text { Country, } \\
\text { city }\end{array}$ & $\begin{array}{l}\text { Sample size, maternal } \\
\text { age }\end{array}$ & $\begin{array}{l}\text { Definition of } \\
\text { periodontitis }\end{array}$ & $\begin{array}{l}\text { Time of } \\
\text { examination }\end{array}$ & $\begin{array}{l}\text { OR } \\
(95 \% \mathrm{CI})\end{array}$ & $\begin{array}{l}\text { Adjustment of } \\
\text { factors }\end{array}$ \\
\hline Boggess et al. [18] 2003 & $\begin{array}{l}\text { USA Chapel } \\
\text { Hill }\end{array}$ & $\begin{array}{l}763 \text { women, } 39 \text { with PE } \\
\text { Age } 18-35\end{array}$ & $\begin{array}{l}\text { PD with } \\
\text { BoP }>3 \mathrm{~mm}\end{array}$ & $\begin{array}{l}\text { 1st visit }<26 \text { weeks, } \\
\text { next } 26-36 \text { weeks }\end{array}$ & $\begin{array}{l}2.4(1.1-5.3) \\
\text { For heavy } P\end{array}$ & $\begin{array}{l}\text { Maternal age, race, } \\
\text { insurance, smoking }\end{array}$ \\
\hline Srinivas et al. [19] 2009 & $\begin{array}{l}\text { USA } \\
\text { Philadelphia }\end{array}$ & $\begin{array}{l}786 \text { women, } 48 \text { with } \mathrm{PE} \\
\text { Mean age } 23.9\end{array}$ & $\begin{array}{l}\mathrm{PD} \text { and } \\
\mathrm{CAL} \geq 3 \mathrm{~mm}\end{array}$ & $\begin{array}{l}\mathrm{PD} \text { and } \\
\mathrm{CAL} \geq 3 \mathrm{~mm}\end{array}$ & $0.71(0.37-1.36)$ & $\begin{array}{l}\text { Maternal age, race, } \\
\text { smoking, obesity }\end{array}$ \\
\hline Shetty et al. [20] 2010 & $\begin{array}{l}\text { India } \\
\text { Mangalore }\end{array}$ & $\begin{array}{l}130 \text { women, } 30 \text { with } P E \\
\text { Mean age } 26.8\end{array}$ & $\begin{array}{l}P D \geq 4 \mathrm{~mm} \\
C A L \geq 3 \mathrm{~mm}\end{array}$ & $\begin{array}{l}1 \text { st visit }<26 \text { weeks, } \\
\text { next } 26-36 \text { weeks } \\
\text { and within } 2 \text { days } \\
\text { after delivery }\end{array}$ & $\begin{array}{l}\mathbf{5 . 7 8} \\
(2.41-13.89)\end{array}$ & $\begin{array}{l}\text { Maternal age, } \\
\text { education, income }\end{array}$ \\
\hline Kumar et al. [21] 2014 & $\begin{array}{l}\text { India New } \\
\text { Delhi }\end{array}$ & $\begin{array}{l}504 \text { women, } 51 \text { with PE } \\
\text { Age } 20-35\end{array}$ & $\begin{array}{l}\text { PD and } \\
C A L \geq 4 \mathrm{~mm}\end{array}$ & $\begin{array}{l}\text { 1st visit } 14-18 \\
\text { weeks, next after } \\
20 \text { weeks }\end{array}$ & $\begin{array}{l}\mathbf{2 . 6 6} \\
(1.32-5.73)\end{array}$ & $\begin{array}{l}\text { Maternal age, } \\
\text { education, BMI, } \\
\text { income }\end{array}$ \\
\hline Ha et al. [22] 2014 & Korea Seoul & $\begin{array}{l}283 \text { women, } 13 \text { with PE } \\
\text { Mean age } 32.8 \\
(25-40)\end{array}$ & $\mathrm{CAL} \geq 3 \mathrm{~mm}$ & $\begin{array}{l}\text { 1st visit } 21-24 \\
\text { weeks, next after } \\
26 \text { weeks }\end{array}$ & $\begin{array}{l}\mathbf{4 . 5 1} \\
(1.13-17.98)\end{array}$ & $\begin{array}{l}\text { Maternal age, BMI, } \\
\text { health \& oral health } \\
\text { behaviors }\end{array}$ \\
\hline $\begin{array}{l}\text { Soucy-Giguère et al. } \\
\text { [23] } 2016\end{array}$ & $\begin{array}{l}\text { Canada } \\
\text { Quebec }\end{array}$ & $\begin{array}{l}258 \text { women, } 14 \text { with PE } \\
\text { Mean age } 35(19-45)\end{array}$ & $\begin{array}{l}\text { PD with } \\
\text { BoP }>4 \mathrm{~mm}\end{array}$ & $\begin{array}{l}\text { 1st visit } 15-24 \\
\text { weeks, } \\
\text { next after } 26 \text { weeks } \\
\text { and after delivery }\end{array}$ & $\begin{array}{l}\mathbf{5 . 8 9} \\
(1.24-28.05)\end{array}$ & BMI, smoking \\
\hline
\end{tabular}

Table 2. Summary of intervention studies included in the present systematic review

\begin{tabular}{|c|c|c|c|c|c|c|}
\hline Study/Year & $\begin{array}{l}\text { Country, } \\
\text { city }\end{array}$ & $\begin{array}{l}\text { Sample size of the } \\
\text { study and control } \\
\text { groups, maternal age }\end{array}$ & $\begin{array}{l}\text { Definition of } \\
\text { periodontitis }\end{array}$ & $\begin{array}{l}\text { Kind of } \\
\text { intervention }\end{array}$ & $\begin{array}{l}\text { Periodontal } \\
\text { treatment time }\end{array}$ & $\begin{array}{l}\text { RR } \\
(95 \% \mathrm{Cl})\end{array}$ \\
\hline $\begin{array}{l}\text { Michalowicz et al. [24] } \\
2006\end{array}$ & $\begin{array}{l}\text { USA } \\
\text { Minneapolis }\end{array}$ & $\begin{array}{l}\text { IG: } 407 \text { (31 PE) } \\
\text { CG: } 405 \text { ( } 20 \text { PE) } \\
\text { Mean age } 26\end{array}$ & $\begin{array}{l}\mathrm{PD} \geq 4 \mathrm{~mm} \\
\mathrm{CAL} \geq 2 \mathrm{~mm}\end{array}$ & $\begin{array}{l}\text { IG: Hand and } \\
\text { ultrasonic SRP }\end{array}$ & $\begin{array}{l}\text { Before } 21 \text { weeks of } \\
\text { gestation, monthly } \\
\text { control }\end{array}$ & $\begin{array}{l}1.54 \\
(0.89-2.66)\end{array}$ \\
\hline $\begin{array}{l}\text { Offenbacher et al. [25] } \\
2009\end{array}$ & $\begin{array}{l}\text { USA } \\
\text { San Antonio } \\
\text { Tuscaloosa }\end{array}$ & $\begin{array}{l}\text { IG: } 880(67 P E) \\
\text { CG:882 (74 PE) } \\
\text { Mean age } 25.4\end{array}$ & $\mathrm{CAL} \geq 3 \mathrm{~mm}$ & $\begin{array}{l}\text { IG: Hand and } \\
\text { ultrasonic SRP }\end{array}$ & $\begin{array}{l}\text { Before } 23 \text { weeks of } \\
\text { gestation, no follow-up } \\
\text { visits during pregnancy }\end{array}$ & $\begin{array}{l}0.9 \\
(0.66-1.24)\end{array}$ \\
\hline $\begin{array}{l}\text { Newnham et al. [26] } \\
2009\end{array}$ & $\begin{array}{l}\text { Australia } \\
\text { Perth }\end{array}$ & $\begin{array}{l}\text { IG: } 538(18 P E) \\
\text { CG: } 540(22 \mathrm{PE}) \\
\text { Mean age } 30.5\end{array}$ & $\mathrm{PD} \geq 4 \mathrm{~mm}$ & $\begin{array}{l}\text { IG: SRP and } \\
\text { rinsing with } 0.12 \% \\
\text { chlorhexidine } \\
\text { mouthwash }\end{array}$ & $\begin{array}{l}20-24 \text { weeks of gestation, } \\
28-31 \text { weeks and control } \\
\text { visit } 32-36 \text { weeks }\end{array}$ & $\begin{array}{l}0.82 \\
(0.44-1.56)\end{array}$ \\
\hline
\end{tabular}

oral cavity) was performed in 1825 women, out of whom $116(6.36 \%)$ were subsequently diagnosed with PE. In the control group (where only oral hygiene was performed and supra-gingival plaque was removed), $116(6.35 \%)$ out of the 1827 examined women were diagnosed with PE. RCTs were carried out only in the USA and Australia.

\section{DISCUSSION}

It is a well-known fact that cohort and randomized interventional controlled trials have the strongest evidential value in establishing a causal relationship between two pathologies. Therefore, clinical-control and cross-sectional studies were deliberately excluded from this review. The relatively high (over 7\%) percentage of women with PE in the included studies resulted from the fact that the study populations comprised non-Caucasian subjects. The cohort trials clearly indicated that periodontitis may result in an increased risk for developing PE in pregnancy (by 5-fold according to some sources). This relationship has also been confirmed by all three meta-analyses carried out in this field [27-29] so far. In all studies included in the meta-analyses, periodontitis was as an independent factor. Sgolastra et al. [27], after taking into account 12 clinical-control trials and 3 cohort studies from 2003-2012 in the random effects model, obtained the OR at the level of 2.17 (1.38-3.41), although with high and significant heterogenicity (only 8 studies confirmed the relevance of this relationship). Wei et al. [28], after including 13 clinical-control trials and 2 cohort studies from 2003-2012, using a random effects model, confirmed that the probability of developing PE among pregnant women with periodontitis was 3-fold higher with respect to gingivitis or healthy periodontium during pregnancy (OR -2.79 , $\mathrm{Cl}$ - from 2.01 to 3.01). A significant heterogeneity among these studies has also been demonstrated ( 13 confirmed 
the relevance of this association). Also, Huang et al. [29], by including 8 clinical-control and 3 cohort studies from 2003-2013, obtained in their model the OR at the level of 2.69 with a $95 \%$ confidence interval of $1.74-4.17$. Nine studies reported a statistically significant relationship between periodontitis and PE. The subsequent meta-analysis demonstrated a significant impact of common risk factors (socio-economic status and obesity) on both pathologies, and sample size and the quality of the included studies on the strength of the relationship.

The etiopathological mechanisms providing an explanation for the link between periodontitis and PE remain to be fully elucidated. However, it seems that the destroyed attachment apparatus is the source of direct infection of the uteroplacental organ with perio-pathogens. The presence of Porphyromonas gingivalis, Fusobacterium nucleatum, Aggregatibacter actinomycetemcomitans, Tannerella forsythia and Micromonas micros in the placental-fetal unit, in chorionic trophoblasts, and in several types of cells such as amniotic epithelial, decidual, vascular and in the amniotic fluid was demonstrated [30]. Extremely significant similarities between the oral cavity microorganisms and the placenta were found [30]. On the other hand, inflammatory mediators, prooxidative factors, endo- and exotoxins and soluble forms of the adhesion molecules, which induce inflammation of the uteroplacental area, hypoxia, oxidative stress, endothelial dysfunctions leading to $\mathrm{PE}$, penetrate into the cardiovascular bed as a result of periodontal inflammation [31].

From the clinical point of view, reduced incidence of PE by modifying the risk factor, in this case the periodontological treatment, is vital. That possibility has not been confirmed by previous studies, which seems to contradict the presented cohort observations or the aggregated results of the clinical-control and cohort studies in the meta-analyses. A meta-analysis of Kunnen et al. [32], based on the same three randomized interventional studies characterized in Table 2, demonstrates, in the randomized effects model, a lack of effect on PE - the overall RR $1.0(0.78-1.28)$ with respect to no non-surgical treatment of periodontitis being conducted. This was also confirmed by the subsequent meta-analysis of Iheozor-Ejiofor et al. [33], which included the 2 described studies [24,25] and the highly questionable study of 2000 - the overall RR was 1.1 (0.74-1.62). Additionally, very poor evidential quality of the combined studies, high risk of an error in a publication, and serious imprecision were emphasized by the authors. The fact that no protective effect of periodontal treatment on the development of $\mathrm{PE}$ is observed may be explained in two ways. First of all, it should be noted that the treatment of periodontitis was performed too late to affect the possible development of PE — by way of example, in the study by Newnham et al. [26] the treat- ment was started between 20 to 24 weeks of gestation. In the case of an early PE, there is no possibility that such treatment will have a preventive effect. Secondly, it remains unclear to what extent the classical protocol of non-surgical treatment of periodontitis (SRP) during pregnancy protects from the exposure to perio-pathogens and proinflammatory biomarkers. Such treatment significantly reduces the number of perio-pathogens in the periodontal pockets, but it does not eradicate them [34], thus failing to eliminate the source of maternal infection. Similarly, such treatment does not significantly reduce proinflammatory biomarkers in the serum and the umbilical cord blood [35] and, as it was indicated in one of the studies, a significant increase in serum TNF- $a$, IL-8 and MCP1 (monocyte chemotactic protein) was demonstrated after SRP had been performed in pregnant women [36]. If these two suggestions are true, then in the subsequent interventional studies, initiation of the non-surgical treatment between 12 to 16 weeks of pregnancy and improvement of its effectiveness (SRP in combination with supplemental antibiotic administration or antimicrobial photodynamic therapy) may have some effect on PE prevalence. However, methodologically improved interventional tests in pregnant women should certainly be continued, since it is difficult to exclude a positive influence of professional periodontal treatment on various complications of pregnancy.

The present review of the literature about the relationship between periodontitis and preeclampsia is not without limitations. Firstly, there are considerable discrepancies in the definitions of periodontitis, which also applies to Tables 1 and 2. However, if only one definition of periodontitis were to be selected, this would result in rejecting a majority of the analyzed studies. The epidemiological definition of CDC (Center for Disease Control and Prevention) and APP (American Academy of Periodontology) should be preferred, which suggests that at least $2 \mathrm{PD} \geq 4 \mathrm{~mm}$ pockets and at least $2 \mathrm{CAL} \geq 3 \mathrm{~mm}$ spaces on the contacting surfaces are required for such a diagnosis. Out of the 9 works analyzed in the review, this definition was applied only in one case [20]. Stratification of PE severity would also be of great significance. Secondly, the definition of preeclampsia should also be more precise and differentiated into the early and the late PE (with different risk factors), and it should reflect the degree of clinical advancement. Thirdly, to the best of our knowledge, there are no studies on the subject from Europe, including Poland. Extrapolating the research results of the racially, socio-economically and socio-demographically diverse populations to the Polish one is not prudent. This applies particularly to intervention studies, which have so far been carried out in only two highly developed countries - the USA and Australia. The mere diversity of health care systems between countries can create numerous barriers 
for such observations. Next, it is necessary to rigorously monitor as many disruptive factors as possible, including, in particular, common risk factors for both pathologies: maternal age, obesity, socio-economic status and smoking. The development of clear recommendations on the inclusion of these variables in multifactorial analyses in this respect will certainly improve the evidence quality of the studies. Finally, exclusion of publications in Spanish, typically from South America, was a definite limitation.

\section{CONCLUSIONS}

It needs to be emphasized that the relationship between periodontitis and preeclampsia remains controversial. The existing incompatibility between the cohort and randomized trials needs to be further clarified. It is necessary to conduct randomized control trials including Caucasian women, with an accurate effort and attempt to improve the methodology. As a result, periodontal treatment would not only have a beneficial effect on the quality of patient life in relation to oral health, but might also play a role in disease prevention, especially $\mathrm{PE}$, which is associated with significant morbidity and mortality. PE constitutes a serious threat to the health and life of both, the mother and the fetus. Thus, any potential modifiable risk factor must be clearly established in terms of strength, dose-effect relationship and reversibility.

\section{Funding}

The publication was prepared under the project financed from the funds granted by the Ministry of Science and Higher Education in the "Regional Initiative of Excellence" programme for the years 2019-2022, project number 016/RID/2018/19, the amount of funding 11998121.30 PLN.

\section{REFERENCES}

1. Górska R, Dembowska E, Pietruska M, et al. Częstość występowania chorób przyzębia i chorób błony śluzowej jamy ustnej u osób w wieku 35-44 i 65-74 lata w wybranych miastach Polski. Streszczenia 12 Kongresu tologów Polskich. J Stoma. 2014; 67(Supl. 1): 57.

2. AlJehani YA. Risk factors of periodontal disease: review of the literature. Int J Dent. 2014; 2014: 182513, doi: 10.1155/2014/182513, indexed in Pubmed: 24963294.

3. Borakowska-Siennicka M. Stan przyzębia i higieny jamy ustnej u kobiet ciężarnych. Nowa Stomatol. 2002; 7(4): 199-203.

4. Gaszyńska E, Klepacz-Szewczyk J, Trafalska E, et al. Dental awareness and oral health of pregnant women in Poland. Int J Occup Med Environ Health. 2015; 28(3):603-611, doi: 10.13075/ijomeh.1896.00183, indexed in Pubmed: 26190735.

5. Konopka T, Paradowska-Stolarz A. Periodontitis and risk of preterm birth and low birthweight--a meta-analysis. Ginekol Pol. 2012; 83(6):446-453, indexed in Pubmed: 22880465

6. Journal of Clinical Periodontology. 2013; 40(1).

7. Steegers E, Dadelszen Pv, Duvekot J, et al. Pre-eclampsia. The Lancet. 2010; 376(9741): 631-644, doi: 10.1016/s0140-6736(10)60279-6.

8. Poon L, Shennan A, Hyett J, et al. The International Federation of Gynecology and Obstetrics ( FIGO) initiative on pre-eclampsia: A pragmatic guide for first-trimester screening and prevention. International Journal of Gynecology \& Obstetrics. 2019; 145(S1): 1-33, doi: 10.1002/ijgo.12802.
9. Poprawski G. Markery predykcji stanu przedrzucawkowego a przebieg ciąży powikłanej cukrzycą przedciążową. Praca doktorska (Doctoral thesis), UM w Poznaniu. ; 2014: 10-22.

10. Bartsch E, Medcalf KE, Park AL, et al. High Risk of Pre-eclampsia Identification Group. Clinical risk factors for pre-eclampsia determined in early pregnancy: systematic review and meta-analysis of large cohort studies. BMJ. 2016; 353: i1753, doi: 10.1136/bmj.i1753, indexed in Pubmed: 27094586.

11. Riché EL, Boggess KA, LieffS, et al. Periodontal disease increases the risk of preterm delivery among preeclamptic women. Ann Periodontol. 2002; 7(1): 95-101, doi: 10.1902/annals.2002.7.1.95, indexed in Pubmed: 16013222.

12. Moher D, Liberati A, Tetzlaff J, et al. PRISMA Group, PRISMA Group, PRISMA Group, PRISMA Group, PRISMA Group, PRISMA Group, PRISMA Group. Preferred reporting items for systematic reviews and meta-analyses: the PRISMA Statement. Open Med. 2009; 3(3): e123-e130, indexed in Pubmed: 21603045

13. Kumar A, Basra M, Begum N, et al. Association of maternal periodontal health with adverse pregnancy outcome. J Obstet Gynaecol Res. 2013; 39(1): 40-45, doi: 10.1111/j.1447-0756.2012.01957.x, indexed in Pubmed: 22845916.

14. Horton AL, Boggess $\mathrm{KA}$, Moss $\mathrm{KL}$, et al. Periodontal disease, oxidative stress, and risk for preeclampsia. J Periodontol. 2010; 81(2): 199-204, doi: 10.1902/jop.2009.090437, indexed in Pubmed: 20151797.

15. Lee HJ, Ha JE, Bae KH. Synergistic effect of maternal obesity and periodontitis on preterm birth in women with pre-eclampsia: a prospective study. J Clin Periodontol. 2016; 43(8): 646-651, doi: 10.1111/jcpe.12574, indexed in Pubmed: 27167920.

16. Herrera JA, Velez-Medina S, Molano R, et al. Periodontal intervention effects on pregnancy outcomes in women with preeclampsia. Colomb Med. 2009; 40(2): 177-184.

17. Boggess KA, Berggren EK, Koskenoja $V$, et al. Severe preeclampsia and maternal self-report of oral health, hygiene, and dental care. J Periodontol. 2013; 84(2): 143-151, doi: 10.1902/jop.2012.120079, indexed in Pubmed: 22509752.

18. Boggess KA, Lieff $S$, Murtha AP, et al. Maternal periodontal disease is associated with an increased risk for preeclampsia. Obstet Gynecol. 2003; 101(2): 227-231, doi: 10.1016/s0029-7844(02)02314-1, indexed in Pubmed: 12576243.

19. Srinivas SK, Sammel MD, Stamilio DM, et al. Periodontal disease and adverse pregnancy outcomes: is there an association? Am J Obstet Gynecol. 2009; 200(5): 497.e1-497.e8, doi: 10.1016/j.ajog.2009.03.003, indexed in Pubmed: 19375568.

20. Shetty M, Shetty PK, Ramesh A, et al. Periodontal disease in pregnancy is a risk factor for preeclampsia. Acta Obstet Gynecol Scand. 2010; 89(5): 718721, doi: 10.3109/00016341003623738, indexed in Pubmed: 20196677.

21. Kumar A, Begum N, Prasad S, et al. Role of cytokines in development of pre-eclampsia associated with periodontal disease-Cohort Study. J Clin Periodontol. 2014; 41(4): 357-365, doi: 10.1111/jcpe.12226, indexed in Pubmed: 24393049.

22. Ha JE, Jun JK, Ko HJ, et al. Association between periodontitis and preeclampsia in never-smokers: a prospective study. J Clin Periodontol. 2014; 41(9): 869-874, doi: 10.1111/jcpe.12281, indexed in Pubmed: 24930492.

23. Soucy-Giguère $L$, Tétu $A$, Gauthier $S$, et al. Periodontal Disease and Adverse Pregnancy Outcomes: A Prospective Study in a Low-Risk Population. J Obstet Gynaecol Can. 2016; 38(4): 346-350, doi: 10.1016/j. jogc.2016.02.012, indexed in Pubmed: 27208603.

24. Michalowicz BS, Hodges JS, DiAngelis AJ, et al. OPT Study. Treatment of periodontal disease and the risk of preterm birth. N Engl J Med. 2006; 355(18): 1885-1894, doi: 10.1056/NEJMoa062249, indexed in Pubmed: 17079762.

25. Offenbacher S, Beck JD, Jared HL, et al. Maternal Oral Therapy to Reduce Obstetric Risk (MOTOR) Investigators. Effects of periodontal therapy on rate of preterm delivery: a randomized controlled trial. Obstet Gynecol. 2009; 114(3): 551-559, doi: 10.1097/AOG.0b013e3181b1341f, indexed in Pubmed: 19701034

26. Newnham JP, Newnham IA, Ball CM, et al. Treatment of periodontal disease during pregnancy: a randomized controlled trial. Obstet Gynecol. 2009; 114(6): 1239-1248, doi: 10.1097/AOG.0b013e3181c15b40, indexed in Pubmed: 19935025.

27. Sgolastra F, Petrucci A, Severino $M$, et al. Relationship between periodontitis and pre-eclampsia: a meta-analysis. PLoS One. 2013; 8(8): e71387, doi: 10.1371/journal.pone.0071387, indexed in Pubmed: 23990948. 
28. Wei BJ, Chen YJ, Yu Li, et al. Periodontal disease and risk of preeclampsia: a meta-analysis of observational studies. PLoS One. 2013; 8(8): e70901, doi: 10.1371/journal.pone.0070901, indexed in Pubmed: 23951033.

29. Huang Xi, Wang J, Liu J, et al. Maternal periodontal disease and risk of preeclampsia: a meta-analysis. J Huazhong Univ Sci Technolog Med Sci. 2014; 34(5): 729-735, doi: 10.1007/s11596-014-1343-8, indexed in Pubmed: 25318884.

30. Zi M, Longo P, Bueno-Silva B, et al. Mechanisms Involved in the Association between Periodontitis and Complications in Pregnancy. Frontiers in Public Health. 2015; 2, doi: 10.3389/fpubh.2014.00290.

31. Shiadeh MN, Moghadam ZB, Adam I, et al. Human infectious diseases and risk of preeclampsia: an updated review of the literature. Infection. 2017; 45(5): 589-600, doi: 10.1007/s15010-017-1031-2.

32. Kunnen A, van Doormaal JJ, Abbas F, et al. Periodontal disease and pre-eclampsia: a systematic review. J Clin Periodontol. 2010; 37(12): 1075-1087, doi: 10.1111/j.1600-051X.2010.01636.x, indexed in Pubmed: 21070324
33. Iheozor-Ejiofor Z, Middleton $\mathrm{P}$, Esposito $\mathrm{M}$, et al. Treating periodontal disease for preventing adverse birth outcomes in pregnant women. Cochrane Database Syst Rev. 2017; 6: CD005297, doi: 10.1002/14651858. CD005297.pub3, indexed in Pubmed: 28605006.

34. Novak MJ, Novak KF, Hodges JS, et al. Periodontal bacterial profiles in pregnant women: response to treatment and associations with birth outcomes in the obstetrics and periodontal therapy (OPT) study. J Periodontol. 2008; 79(10): 1870-1879, doi: 10.1902/jop.2008.070554, indexed in Pubmed: 18834241.

35. Pirie $M$, Linden G, Irwin C. Intrapregnancy non-surgical periodontal treatment and pregnancy outcome: a randomized controlled trial. J Periodontol. 2013; 84(10): 1391-1400, doi: 10.1902/jop.2012.120572, indexed in Pubmed: 23237583.

36. Penova-Veselinovic B, Keelan JA, Wang CA, et al. Changes in inflammatory mediators in gingival crevicular fluid following periodontal disease treatment in pregnancy: relationship to adverse pregnancy outcome. J Reprod Immunol. 2015; 112: 1-10, doi: 10.1016/j.jri.2015.05.002, indexed in Pubmed: 26093363. 